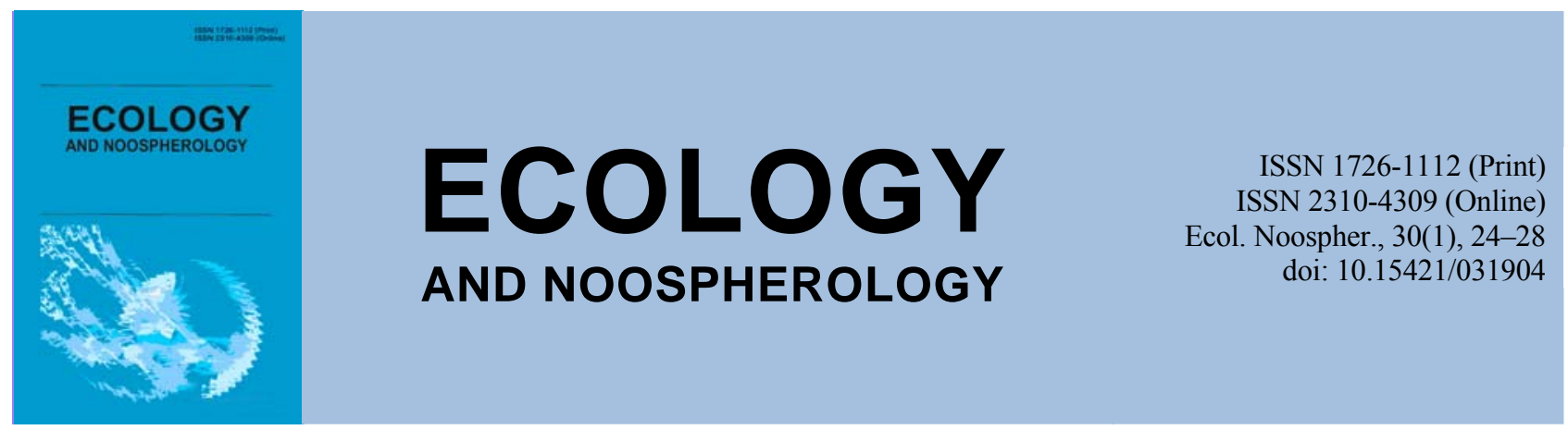

\title{
Trophic selectivity of litter saprophages (Diplopoda, Isopoda) in natural forests in the steppe conditions
}

\author{
A. P. Pokhylenko*, O. O. Didur*, Yu. L. Kulbachko*, Yu. Yu. Ovchynnykova** \\ * Oles Honchar Dnipro National University, Dnipro, Ukraine \\ **Vasyl Stus Donetsk National University, Vinnytsia, Ukraine
}

Article info

Received 18.02.2019

Received in revised form 24.02.2019

Accepted 02.03.2019

Oles Honchar Dnipro

National University,

Gagarin Ave., 72, Dnipro,

49010, Ukraine.

Tel.: +38-096-389-78-75

E-mail:vivtash@ukr.net

Vasyl Stus Donetsk National

University, 600-richcha Str., 21

Vinnytsia, 21021, Ukraine.
Pokhylenko, A. P., Didur, O. O., Kulbachko, Yu. L., Ovchynnykova, Yu. Yu. (2019). Trophic selectivity of litter saprophages (Diplopoda, Isopoda) in natural forests in the steppe conditions. Ecology and Noospherology, 30(1), 24-28. doi:10.15421/031904

The forest litter serves as a bridge between the above ground forest flora and fauna with the soil. Trophic activity of soil invertebrates affects the decomposition processes of plant organic residues and, thus, on the forest soils fertility. It is a natural mechanism that positively influences on maintenance and improvement of natural soils properties. The object of this study is the representatives of Diplopoda Rossiulus kessleri (Lohmander, 1927) and Isopoda Porcellio scaber (Latreille, 1804). The aim of the paper is to qualify the trophic preferences of the saprophages, as soil invertebrate representatives, of natural forest ecosystems in conditions of the steppe zone of Ukraine. To identify the ecological role of millipedes and woodlice as primary destructors of leaf litter, we made a field experiment studying their trophic preferences with the use of microcosms. Microcosms (containers) were filled with soil free from invertebrates; after it added a certain mixture of leaf litter and saprophages representatives. To analyze the decomposition rate of leaf litter the percentage of consumed litter was determined by calculating air-dry mass of leaf litter in the beginning and at the end of experiment. A regression model that reflects the trophic selectivity of saprophages for the following mixture components of such tree species as the common maple (Acer campestre (L.), little-leaved linden (Tilia cordata (Mill.), common oak (Quercus robur (L.), European white elm (Ulmus laevis (Pall.), European ash (Fraxinus excelsior (L.) is proposed. Among other regression model types (linear, quadratic, special cubic), permissible statistical estimates revealed a special cubic mathematical model and it allowed to conclude on the saprophages trophic selectivity. The special cubic regression model has a relatively high performance (the determination coefficient is $87.5 \%$ ) and adequately approximates empirical data with a significance level of less than 0.05. It was found out that common maple and European white elm litter is consumed in a greater quantity than any other litter from suggested. It is confirmed by their main effects coefficients in the regression equation. Thus, the saprophages trophic selectivity persistence in natural forests under the conditions of the steppe zone has been proved. Consequently, the saprophages trophic activity increases with the presence of the maple and European white elm in natural forests, which makes expedient the use of these tree species, in the design of forest stands.

Keywords: ecosystem engineers; ecosystem services; saprophages; millipede (Rossiulus kessleri); trophic priorities; forest ecosystems

\section{Трофічна вибірковість підстилкових сапрофагів (Diplopoda, Isopoda) у природних лісах в умовах степу}

\author{
А. П. Похиленко*, О. О. Дідур*, Ю. Л. Кульбачко*, Ю. Ю. Овчинникова** \\ *Дніпровський національний університет імені Олеся Гончара, Дніпро, Україна \\ **Донеиький національний університет імені Василя Стуса, Вінниця, Україна
}

Лісова підстилка пов'язує рослинний і тваринний світ лісу з грунтом. Трофічна активність грунтових безхребетних впливає на процес розкладання органічних залишків рослинного походження і, врешті-решт, на родючість лісових грунтів. 
Це природний механізм, який позитивно впливає на підтримання і поліпшення властивостей природних грунтів. Об'єкт дослідження - представники Diplopoda (Rossiulus kessleri (Lohmander, 1927), ківсяк сірий), а також Isopoda (Porcellio scaber Latreille, 1804, мокриця звичайна). Мета роботи - з'ясувати трофічну вибірковість сапрофагів, що входять до складу грунтових безхребетних природних лісових екосистем в умовах степової зони України. Для виявлення екологічної ролі ківсяків і мокриць як первинних деструкторів листяного опаду нами проведено польовий експеримент стосовно вивчення їх трофічних переваг із застосуванням мікрокосмів. До мікрокосму - ємності, яку заповнювали грунтом, вільним від безхребетних тварин, певною сумішшю листяного опаду, додавали представників сапрофагів. На початку і в кінці дослідів визначали повітряно-суху масу підстилки. За іiі кількістю до і після експерименту розраховували різницю (відсоток спожитої підстилки), яка є показником швидкості розкладання аналізованої підстилки. Запропоновано регресійну модель, яка відображає трофічну вибірковість сапрофагів до компонентів суміші з опалого листя таких деревних порід, як клен польовий (Acer campestre (L.), липа серцелиста (Tilia cordata (Mill.), дуб звичайний (Quercus robur (L.), в'яз гладкий (Ulmus laevis (Pall.), ясен звичайний (Fraxinus excelsior (L.). Серед інших видів регресійних моделей (лінійна, квадратична, спеціальна кубічна) припустимі статистичні оцінки виявила спеціальна кубічна математична модель, яка дозволила зробити висновок щодо трофічної вибірковості сапрофагів. Спеціальна кубічна регресійна модель має відносно високу працездатність (коефіцієнт детермінації складає 87,5 \%) та адекватно апроксимує емпіричні дані з рівнем значущості менше 0,05. 3'ясовано, що листяний опад клена польового та в'яза гладкого споживається групою сапрофагів, яких залучено до експерименту, у більшій кількості, ніж опади липи серцелистої, дуба звичайного та ясена звичайного, про що свідчать їх коефіцієнти основних ефектів у рівнянні регресії. Таким чином, доведено збереження у сапрофагів у природних лісах в умовах степової зони трофічної вибірковості. Отже, трофічна активність сапрофагів збільшується за присутності в природних лісах клена польового і в'яза гладкого, що робить доцільним використання цих деревних порід навіть у конструюванні штучних лісових екосистем.

Ключові слова: екосистемні інженери; екосистемні послуги; діплоподи; ківсяк (Rossiulus kessleri); трофічні пріоритети; лісові екосистеми

\section{Вступ}

На сьогодні лісистість України становить 15,9 \%, майже половина лісів $\epsilon$ штучними, що потребує посиленого догляду. Одним з найважливіших компонентів лісової екосистеми $\epsilon$ листяний опад - основа для гуміфікації - 3 властивостями, запасом і типом якого пов'язаний важливий для цієї екосистеми кругообіг речовин і енергії. Накопичення маси листяного опаду в природних і штучних лісових екосистемах залежить не тільки від видового складу, але й від зімкнутості деревного ярусу та водно-теплового режиму під пологом лісу. Склад, вік та зімкнутість деревостану мають вирішальний вплив на масу листяного опаду, яка протягом життя одного покоління лісу змінюється в декілька разів (Martinovich et al., 1998; Brygadyrenko, 2016; Wallace et al., 2018). У листях всіх деревних порід, що опадають, у порівнянні із зеленим листям спостерігається збільшення загальної кількості всіх елементів, у підстилці відбувається подальше збільшення загальної суми елементів за рахунок підвищення вмісту кремнію, магнію, алюмінію, заліза, іноді кальцію, азоту, сірки, маргану й зменшення вмісту калію, хлору, натрію, іноді фосфору (Dubovskaya, 1984).

Залежно від деревної породи, що складає насадження, змінюється не тільки кількість листяного опаду, але й його якісний склад. У тісному взаємозв'язку від якісного складу знаходяться ценози мікроорганізмів і фауни, що населяє листяну підстилку, це приводить до значної різниці у швидкості й продуктах розкладу (Oliveira et al., 2019; Luai et al., 2019; Rossi et al., 2019). Підстилка на довгий час виводить 3 грунтоутворення та біологічного кругообігу величезні маси зольних речовин і біофільних елементів, у листяних лісах вона завжди багатша зольними елементами, відрізняється меншою кислотністю та більшою мірою насиченості, ніж підстилка у хвойних насадженнях (Brygadyrenko, 2016). Дослідження науковців трансформації в лісовій екосистемі відмерлої рослинної речовини підтверджують, що розкладання листяних залишків $\epsilon$ важливим джерелом реактивних органічних сполук під пологом лісу (Chornobay, 2000; Isidorov et al., 2016).

Структура сапрофільних комплексів на рівні надвидових таксонів (родин i рядів) відображає відмінності у властивостях підстилок, які характерні для лісів, утворених різними видами дерев-едифікаторів (різниця в мірі зволоження, вмісту біогенних елементів, мікробіологічній активності). Видовий склад деструкторів $\epsilon$ більш тонким індикатором фізико-хімічних властивостей (зольності, кислотності, складу органічної речовини) лісових підстилок конкретних біотопів і відображає велике диференціювання видів по відношенню до едафічних факторів (Valkova, 2009; Faly, Brygadyrenko, 2018).

Характер накопичення лісової підстилки може бути індикатором антропогенного навантаження на лісовий фітоценоз. Антропогенна дигресія лісового ландшафту починається зі змін лісової підстилки під пологом лісу, iii розподілу за площею. Такі зміни в запасах лісової підстилки призводять до порушення типового для даної лісової екосистеми кругообігу речовин (Martinovich et al., 1998).

Важливою ланкою у здійсненні кругообігу речовин у лісовій екосистемі є хребетні і безхребетні тварини. Серед безхребетних велике значення в кругообігу речовин мають грунтові сапрофаги - типові представники функціональної групи середовищеперетворювачів, або “екосистемних інженерів" (Bulakhov, 2011; Tiunov, 2007; Eisenhauer, 2010; Jones et al., 1994, 1997). Формуючи піонерні угруповання, їх представники першими серед грунтових безхребетних починають біологічне освоєння субстратів природного та антропо-техногенного походження, впливаючи на хід первинних етапів грунтоутворення (Tarashchuk, Bezkrovna, 2000), вступають у складні взаємовідношення з грунтовою мікрофлорою (Stebaev, 1984; Byzov, 2005), формують структуру грунту, запобігають безповоротній втраті гумусу й повній деградації грунту. Вони беруть безпосередню участь не тільки в механічному руйнуванні відмерлої органічної речовини рослинного походження, але й в іiі перемішуванні з мінеральною частиною грунту (Striganova, 1980), прискорюючи тим самим надходження елементів в грунт; вторинний перерозподіл хімічних елементів, подальша біохімічна трансформація органічної речовини гуміфікація (найголовніший грунтовий процес) (Striganova, 1980, 2000) у лісових екосистемах відбувається також за участю грунтових безхребетних (Krivoluckij, 1982). Ця функція грунтових сапрофагів не дублюється іншими групами живих організмів i важлива 3 точки зору збереження та підвищення родючості грунтів.

Однією з важливих задач, пов'язаних 3 дослідженням трофічної діяльності сапрофагів, - дослідження їx трофічних пріоритетів, які визначають їх екологічну роль у функціонуванні екосистем (Roy et al., 2009; Semenyuk et al., 2011; Svyrydchenko, Brygadyrenko, 2014) .

Об'єкт дослідження - представники Diplopoda (Julidae) Rossiulus kessleri (Lohmander, 1927) - сірого ківсяка, а також Porcellio scaber Latreille, 1804 - мокриці звичайної. 
Це еврибіонти, звичайні для лісів та лісосмуг у помірних широтах. Вони беруть активну участь у деструкції опалого рослинного матеріалу та сприяють підвищенню родючості грунту. Мета роботи - з'ясувати трофічну вибірковість сапрофагів, що входять до складу грунтових безхребетних природних лісових екосистем в умовах степової зони України.

\section{Матеріали та методи досліджень}

Дослідження було проведено в польових умовах восени 2017 року на території Присамарського міжнародного біосферного стаціонару імені О. Л. Бельгарда (Новомосковський $\mathrm{p}-\mathrm{H}$ Дніпропетровської обл.). Ця територія відповідає у фізико-географічному відношенні степовій області Придніпровської лівобережної низовини (північна степова підзона, лівобережно-дніпровська північно-степова провінція) і охоплює природні лісові та штучні лісові масиви.
Для встановлення впливу диплопод Rossiulus kessleri (Lohm.) та мокриць Porcellio scaber (Latreille) на деструкцію п'ятикомпонентної суміші листяного опаду з листя клену польового (Acer campestre (L.)) ( $\left.x_{1}\right)$, липи серцелистої (Tilia cordata (Mill.)) $\left(x_{2}\right)$, дуба звичайного (Quercus robur (L.)) $\left(x_{3}\right)$, в'яза гладкого (Ulmus laevis (Pall.)) $\left(x_{4}\right)$, ясена звичайного (Fraxinus excelsior (L.)) $\left(x_{5}\right)$ проведено польовий експеримент із застосуванням мікрокосмів. Мікрокосм являе собою занурену в грунт ємність, яку заповнювали грунтом, вільним від безхребетних тварин, великих коренів, гілок і відмерлого листя дерев, сумішшю листяного опаду. До кожного мікрокосму додавали представників сапрофагів (15 мокриць, 15 диплопод) 3 близькими лінійними розмірами в кожній групі тварин. До експерименту відібрано дорослих особин мокриць і диплопод.

Математичний план експерименту являє собою симплекс-гратчастий тип плану $\{5,3\}$, де 3 - кількість компонентів, 3 - ступінь полінома (Adler et al., 1976). У кожній точці експериментального плану було

Таблиця 1

Матриця планування й позначення відгуків (неповний приклад)

\begin{tabular}{cccccc}
\hline Номер & & \multicolumn{5}{c}{ Склад суміші (частка одиниці) } \\
досліду & Acer campestre $\left(x_{1}\right)$ & Tilia cordata $\left(x_{2}\right)$ & Quercus robur $\left(x_{3}\right)$ & Ulmus laevis $\left(x_{4}\right)$ & Fraxinus excelsior $\left(x_{5}\right)$ \\
\hline 1 & 1 & 0 & 0 & 0 & 0 \\
2 & 0 & 1 & 0 & 0 & 0 \\
3 & 0 & 0 & 1 & 0 & 0 \\
4 & 0 & 0 & 0 & 1 & 0 \\
5 & 0 & 0 & 0 & 0 & 0 \\
6 & 0,5 & 0,5 & 0 & 0 & 0 \\
7 & 0,5 & 0 & 0,5 & 0 & 0 \\
8 & 0,5 & 0 & 0 & 0,5 & 0 \\
9 & 0,5 & 0 & 0 & 0 & 0 \\
10 & 0 & 0,5 & 0,5 & 0 & $\ldots$ \\
$\ldots$ & $\ldots$ & $\ldots$ & $\ldots$ & 0,1 & 0,6 \\
36 & 0,1 & 0,1 & 0,1 & 0
\end{tabular}

реалізовано два паралельних досліди. В експерименті змінні $x_{i}(i=1,2, \ldots q) \in$ пропорціями (відносним умістом) $i$-х компонентів суміші (табл. 1).

Дослід проводили в паклено-ясеневій діброві $\mathrm{Dn}_{3} 3$ потужністю підстилки $3 \mathrm{~cm}$. Виходячи 3 показників середньої повітряно сухої маси підстилки на квадратний метр $\left(400 \Gamma / \mathrm{m}^{2}\right)$ у зазначеному типі лісової екосистеми, до кожного мікрокосму вносили по 23 г повітряно сухої підстилки. Додатково встановили три контрольних мікрокосми. Вимірювали загальну масу суміші листяного опаду до й після експериментального впливу. Дослідження проведено протягом одного місяця.

Статистичне опрацювання даних здійснювали у пакеті програм Statgraphics Centurion XV Version 15.1.02.

\section{Результати та їх обговорення}

Залучення спеціального математичного плану експерименту дозволило описати одержані результати такими регресійними моделями, як лінійна квадратична та спеціальна кубічна. Серед них спеціальна кубічна модель виявила найкращі статистичні оцінки (табл. 2).

Отримане рівняння залежності спожитого сапрофагами листяного опаду від його якісного складу має вигляд:

$y=2,40$ Acer $+1,67$ Tilia $+1,64$ Quercus $+1,77$ Ulmus +

+ 1,42 Fraxinus - 2,12 Acer Tilia + 17,31 Acer Quercus +

+ 7,63 Tilia Ulmus - 49,41 Acer Quercus Ulmus -

- 54,57 Acer Quercus Fraxinus - 52,46 Tilia Ulmus Fraxinus,

де $y$ - маса спожитої підстилки, Acer - відносний уміст у суміші листяного опаду клена гостролистого, Tilia відносний уміст у суміші листяного опаду липи серцелистої, Quercus - відносний уміст у суміші листяного опаду дуба звичайного, Ulmus - відносний уміст у суміші листяного опаду в'яза гладкого, Fraxinus - відносний уміст у суміші листяного опаду ясена звичайного.

У рівнянні залишили статистично значущі $(P \leq 0,05)$ основні фактори та ефекти їх взаємодії. Одним з показників якості регресійної моделі, окрім іï адекватності, $є$ коефіцієнт

Таблица 2

Статистична оцінка адекватності моделей зміни маси листяного опаду

\begin{tabular}{lccccc}
\hline $\begin{array}{c}\text { Вид математичної } \\
\text { моделі }\end{array}$ & Сума квадратів & $\begin{array}{c}\text { Число ступенів } \\
\text { свободи }\end{array}$ & Середній квадрат & $\begin{array}{c}F \text {-відношення } \\
\text { (емпіричне) }\end{array}$ & $\begin{array}{c}\text { Рівень значущості } \\
(P)\end{array}$ \\
\hline Лінійна & 2,99 & 4 & 0,75 & 0,67 & 0,620 \\
Квадратична & 11,39 & 10 & 1,14 & 1,02 & 0,457 \\
Спеціальна кубічна & 18,64 & 10 & 1,87 & 4,34 & 0,012 \\
\hline
\end{tabular}


детермінації. Він показує, яка частина дисперсії результативної ознаки пояснена рівнянням регресії. Чим більший $R^{2}$, тим більша частина дисперсії результативної ознаки пояснюється рівнянням регресії, тим краще рівняння регресії описує вихідні дані. За відсутності залежності між результативною ознакою й незалежною змінною коефіцієнт детермінації $R^{2}$. Оцінка порівняння ступеня апроксимації даних різних регресійних моделей виявила, що спеціальна кубічна модель має найліпші результати: іiі коефіцієнт детермінації, а також скоригований коефіцієнт детермінації достатньо високий і складає 87,5 \% та 60,2 \% відповідно (табл. 3).

Таблиця 3

Статистична оцінка різних видів регресійних моделей

\begin{tabular}{lccc}
\hline \multicolumn{1}{c}{ Вид моделі } & Похибка & Коефіцієнт детермінації $(\mathrm{R})$ & $\begin{array}{c}\text { Скоригований коефіцієнт } \\
\text { детермінації }(\mathrm{R})\end{array}$ \\
\hline Лінійна & 1,059 & 7,91 & 0,00 \\
Квадратична & 1,055 & 38,09 & 0,00 \\
Спеціальна кубічна & 0,655 & 87,48 & 60,17 \\
\hline
\end{tabular}

3'ясовано, що листяний опад клена польового та в'яза гладкого споживається групою сапрофагів, яких залучено до експерименту, у більшій кількості (відповідні коефіцієнти рівняння регресії дорівнюють $+2,40 \mathrm{i}+1,77)$, ніж опади липи серцелистої, дуба звичайного та ясена звичайного.

У запропонованій моделі щодо споживання суміші листяного опаду ефекти високого порядку (четвертого i п'ятого) виявилися статистично незначущими. Внесок інших взаємодій статистично достовірний $\mathrm{i}$ менший порівняно 3 внеском основних ефектів. Для потрійних взаємодій за присутності у багатокомпонентній суміші таких листяних опадів, як дуба звичайного та в'яза гладкого, спостерігається їх менше споживання, про що свідчать від'ємні значення коефіцієнтів регресії.

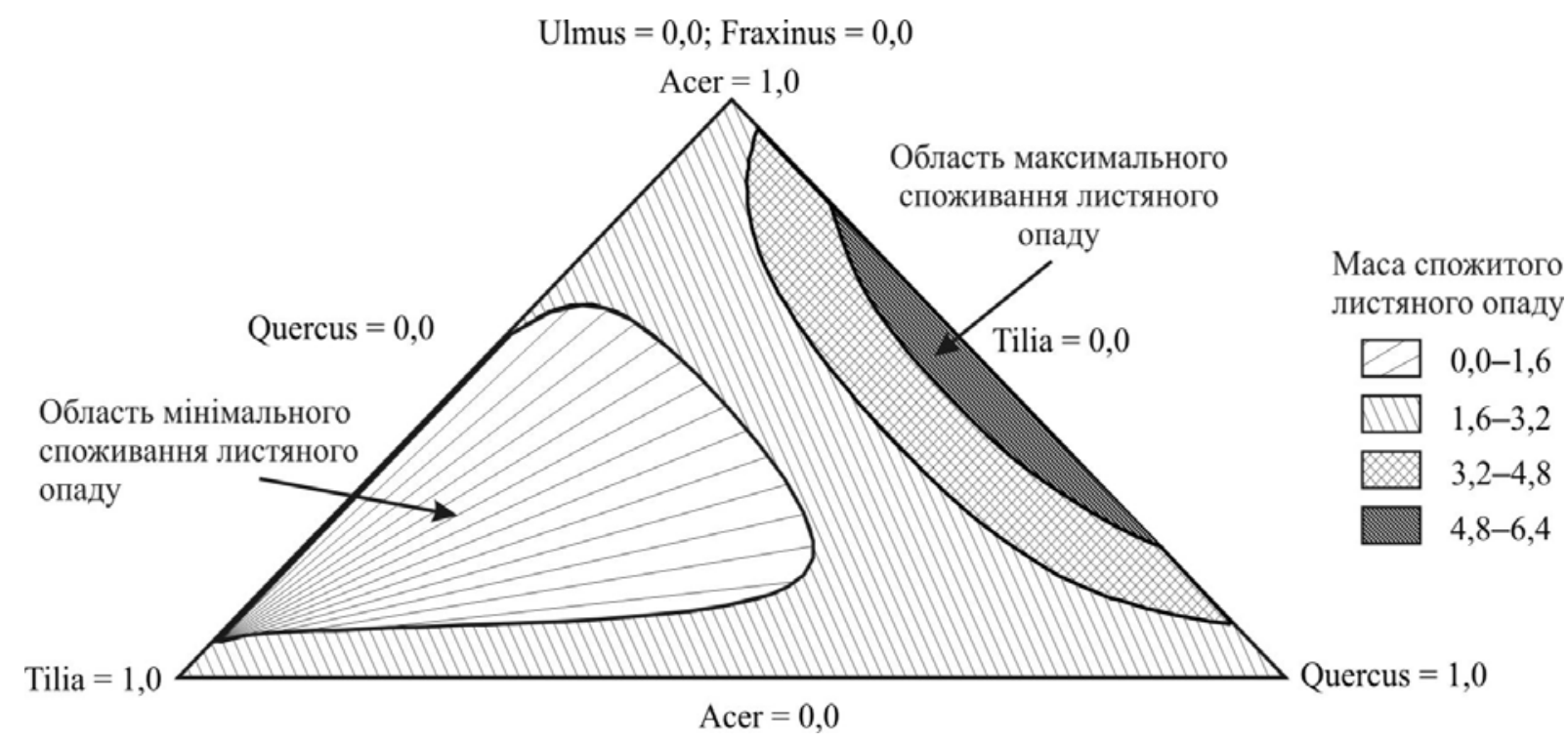

Рис. 1. Трофічні пріоритети R. kessleri (Lohm.) під час споживання листяного опаду п’яти порід дерев

\section{Висновки}

Запропоновано регресійну модель, яка відображає трофічну вибірковість сапрофагів (ківсяк сірий і мокриця звичайна) до компонентів суміші з опалого листя основних деревних порід природних дубрав в умовах степу - клена польового (Acer campestre (L.), липи серцелистої (Tilia cordata (Mill.), дуба звичайного (Quercus robur (L.), в'яза гладкого (Ulmus laevis (Pall.), ясена звичайного (Fraxinus excelsior (L.). Припустимі статистичні оцінки виявила спеціальна кубічна математична модель, яка має відносно високу працездатність (коефіцієнт детермінації складає 87,5\%) та адекватно апроксимує емпіричні дані з рівнем значущості менше 0,05 . За їі допомогою з'ясовано, що в суміші листяного опаду листя клена гостролистого та в'яза гладкого споживаються групою сапрофагів у більшій кількості, ніж опади липи, дуба та ясена. Отже, можна припустити, що трофічна активність сапрофагів збільшується за присутності у природних лісах клена польового i в'яза гладкого, тому $\epsilon$ доцільним

детермінації $R^{2}$ наближатиметься до нуля. Для оцінки якості регресійної моделі 3 великою кількістю факторів використовують скоригований коефіцієнт множинної використання цих деревних порід навіть у ході конструювання штучних лісових екосистем.

\section{Подяка}

Представлені матеріали - частина науково-дослідної роботи «Екологічні основи зоопертинентного впливу тварин на процеси оптимізації природних і порушених екосистем в умовах сучасного природокористування» (номер держреєстрації 0117U001207). Дослідження виконано завдяки фінансовій підтримці Міністерства освіти і науки України.

\section{References}

Adler, Yu. P., Markova, E. V., Granovskij, Yu. V. (1976). Planirovanie ehksperimenta pri poiske optimalnyh uslovij [Planning an experiment when searching for optimal conditions]. Nauka, Moskow (in Russian).

Brygadyrenko, V. (2016). Effect of canopy density on litter invertebrate community structure in pine forests. Ekolygia (Bratislava), 35(1), 90-102. DOI:10.1515/eko-2016-0007. 
Bulakhov, V. L., Pakhomov, O. Ye. (2011). Funkcional'na zoologiya: Pidruchnik. [Functional Zoology: Textbook]. DNU, Dnipropetrovsk (in Ukranian).

Byzov, B. A. (2005). Zoomikrobnye vzaimodejstviya $v$ pochve [Zoomicrobial interactions in the soil]. Geos, Moskow (in Russian).

Chornobay, Yu. M. (2000). Transformatsiya roslinnogo detritu u prirodnikh ekosistemakh [Transformation of plant detritus in natural ecosystems]. DPM NAN Ukraïni, Lviv (in Ukranian).

Dubovskaya, L. V. (1984). Vliyaniye drevesnykh porod na biologicheskiy krugovorot azota i zolnykh elementov $\mathrm{v}$ polezashchitnykh lesnykh polosakh Povolzhia [Effect of tree species on the biological circulation of nitrogen and ash elements in the forest shelter belts of the Povoljya region]. Avtoref. dissert. Volgograd (in Russian).

Eisenhauer, N. (2010). The action of an animal ecosystem engineer: Identification of the main mechanisms of earthworm impacts on soil microarthropods. Pedobiologia, 53(6), 343-352. DOI: 10.1016/j.pedobi.2010.04.003.

Faly, L. I., Brygadyrenko, V. V. (2018). Influence of the herbaceous layer and litter depth on the spatial distribution of litter macrofauna in a forest plantation. Biosystems Diversity, 26(1), 46-51. DOI: 10.15421/011807.

Isidorov, V., Tyszkiewicz, Z., Piroznikow, E. (2016). Fungal succession in relation to volatile organic compounds emissions from Scots pine and Norway spruce leaf litter-decomposing fungi. Atmospheric environment, 131, 301-306. DOI: 10.1016/j.atmosenv.2016.02.015.

Jones, C. G., Lawton, J. H., Shachak, M. (1994). Organisms as ecosystem engineers. Oikos, 69, 373-386. DOI: $10.2307 / 3545850$

Jones, C. G., Lawton, J. H., Shachak, M. (1997). Positive and negative effects of organisms as physical ecosystem engineers. Ecology, 78, 1946-1957. DOI: 10.1890/00129658(1997)078[1946:PANEOO]2.0.CO;2.

Krivoluckij, D. A., Pokarzhevskij, A. D., Mihal'cova, Z. A. (1982). Rol nazemnyh i pochvennyh bespozvonochnyh v biogennoj migracii zolnyh ehlementov i ee osobennosti v Podmoskove [The role of terrestrial and soil invertebrates in the biogenic migration of ash constituents, and its features in the Moscow region]. Bioindikaciya sostoyaniya okruzhayushchej sredy Moskvy i Podmoskovya. Nauka, Moskow, 82-92 (in Russian).

Luai, V. B., Ding, S. B., Wang, D. (2019). The effects of litter quality and living plants on the home-field advantage of aquatic macrophyte decomposition in a eutrophic urban lake, China. Science of the total environment, 650(1), 1529-1536. DOI: 10.1016/j.scitotenv.2018.09.104.

Martinovich, B. S., Yakushev, B. I., Vlasov, V. K., Afinogenov, A. M., Golushko, R. M., Sak, M. M. (1998). Mezhvidovaya spetsifika akkumulyatsi radionuklidov drevesiny i rasteniy [Interspecific specifics radionuclide accumulation in trees and plants] «Lesnoy kompleks: sostoyaniye i perspektivy razvitiya» Mezhdunarodnaya nauchno-tekhnicheskaya konferentsiya Minsk, (in Russian).
Oliveira, R. A. C., Marques, R., Marques, M. C. M. (2019). Plant diversity and local environmental conditions indirectly affect litter decomposition in a tropical forest. Applied soil ecology, 134, 45-53. DOI: 10.1016/j.apsoil.2018.09.016.

Rossi, F., Mallet, C., Portelli, C., Donnadieu, F., Bonnemoy, F., Artigas, J. (2019). Stimulation or inhibition: Leaf microbial decomposition in streams subjected to complex chemical contamination. Science of the total environment, 648, 1371-1383. DOI: 10.1016/j.scitotenv.2018.08.197.

Roy, S. N., Joy, V. C. (2009). Dietary effects of non-nutrients in the leaf litter of forest trees on assimilation, growth and tissue composition of the detritivorous soil arthropod Anoplodesmus saussurei (Humb.) (Polydesmida: Diplopoda). Applied Soil Ecology, 43, 53-60. DOI: 10.1016/j.apsoil.2009.06.009.

Semenyuk, I. I., Tiunov, A. V. (2011). Isotopic signature $(15 \mathrm{~N} / 14 \mathrm{~N}$ and $13 \mathrm{C} / 12 \mathrm{C})$ confirms similarity of trophic niches of millipedes (Myriapoda, Diplopoda) in a temperate deciduous forest. Biological Bulletin, 38, 283-291.

Stebaev, I. V. (1984). Zoomikrobioticheskie kompleksy v bioegocenozah (osnovnye itogi i perspektivy izucheniya) [Zoomicrobiotic complexes in bioecenoses (main results and prospects for further researching]. Pochvennye organizmy kak komponenty biogeocenoza, Nauka, Moskow, 40-53 (in Russian).

Striganova, B. R. (1980). Pitanie pochvennyh saprofagov [The feeding of soil saprophages]. Nauka, Moskow (in Russian).

Striganova, B. R. (2000). Lokomotornaya i troficheskaya aktivnost' bespozvonochnyh kak faktor formirovaniya pochvennoj struktury [Locomotor and trophic activity of invertebrates as a factor of the soil structure formation]. Pochvovedenie, 10, 1247-1254 (in Russian).

Svyrydchenko, A. O., Brygadyrenko, V. V. (2014). Trophic preferences of Rossiulus kessleri (Diplopoda, Julidae) for the litter of various tree species. Folia oecologica, 41, 202-212.

Tarashchuk, M. V., Bezkrovna, O. V. (2000). Vikoristannya sinekologichnih pokaznikiv kolembol (Collembola, Entognatha) dlya ocinki efektivnosti rekul'tivaciï rruntu [Use of cynecological indicators of colembollans (Collembola, Entognatha) to evaluate the efficiency of soil remediation]. Visnik Dnipropetrovs'kogo universitetu. Seriya Biologiya. Ekologiya, 1(8), DDU, Dnipropetrovsk, 49-58 (in Ukranian).

Tiunov, A. V. (2007). Metabioz v pochvennoj sisteme: vliyanie dozhdevyh chervej na strukturu i funkcionirovanie pochvennoj bioty [Metabiosis in the soil system: the effect of earthworms on the structure and functioning of soil biota]. Avtoref. dissert. Moskow (in Russian).

Valkova, S. A. (2009). Kompleksy bespozvonochnykh-saprofagov $\mathrm{v}$ lesnykh ekosistemakh Kolskogo Severa. [Complexes of invertebrate saprophages in forest ecosystems of Kola Peninsula]. Avtoref. dissert. Apatity (in Russian).

Wallace, K. J., Laughlin, D. C., Clarkson, B. D., Schipper, L. A. (2018). Forest canopy restoration has indirect effects on litter decomposition and no effect on denitrification. Ecosphere, 9(12), e02534. DOI: 10.1002/ecs2.2534. 